\title{
Qualitative and quantitative changes in protein synthesis occur at the 8-16-cell stage of embryogenesis in the cow
}

\author{
R. E. Frei, G. A. Schultz* and R. B. Church \\ Department of Medical Biochemistry, The University of Calgary, 3330 Hospital Drive N.W., \\ Calgary, Alberta, Canada T2N $4 \mathrm{N1}$
}

\begin{abstract}
Summary. Cow oocytes and preimplantation embryos were cultured in medium containing radiolabelled methionine and the proteins synthesized were analysed by one-dimensional electrophoresis and fluorography. Marked changes in the pattern of synthesis were observed at the 8-16-cell stage of development. Quantitatively, a gradual decrease in the rate of protein synthesis occurred between the zygote and 8-cell stage and then the rate increased progressively to the blastocyst stage. Incorporation of radiolabelled uridine into RNA was first detected at the 16-cell stage. Taken together, these results suggest that protein synthesis is programmed by maternal mRNA up to the 8-cell stage but switches to mRNA derived from the zygote genome between the 8- and 16-cell stage.
\end{abstract}

Keywords: embryo; maternal mRNA; transcription; translation; cow

\section{Introduction}

The earliest stages of embryogenesis, including those of mammalian embryos, are dependent upon stored products of the maternal genome. During oogenesis, populations of both maternal RNA and protein are accumulated within the oocyte that are sufficient for the progression of the embryo through the first cleavage division in the mouse embryo (Golbus et al., 1973; Braude et al., 1979), the second cleavage division of the human embryo (Braude et al., 1988) and the third cleavage division of the rabbit (Manes, 1973) and the sheep embryo (Crosby et al., 1988). Subsequent embryonic development is dependent upon transcriptional activation of the zygote genome. The switch from maternal to zygote genome control of development is characterized by major changes in the pattern of protein synthesis (Van Blerkom \& Manes, 1974; Flach et al., 1982; Norris et al., 1985; Braude et al., 1988; Crosby et al., 1988).

In this study we examined RNA and protein synthesis to determine when the switch from maternal to zygote genome control of development occurs in the preimplantation cow embryo.

\section{Materials and Methods}

\section{Superovulation and collection of oocytes and embryos}

Heifers and cows of mixed breeds, aged 2-5 years, were obtained from ranch herds in southern Alberta and palpated rectally. Animals with normal reproductive tracts and with active ovaries were injected intramuscularly (i.m.) with 3000 i.u. PMSG (Laboratorio Elea S.A.C.I.F., Buenos Aires, Argentina) on Day $10-12$ of the oestrous cycle, followed after 3 days by i.m. injection of $750 \mu \mathrm{g}$ cloprostenol (Estrumate; Coopers, Willowdale, Canada). Induced oestrus was detected by the onset of standing heat $1.5-2$ days later, and if fertilized eggs were desired, the animals were inseminated artificially 12 and $24 \mathrm{~h}$ after the onset of oestrus.

${ }^{*}$ Reprint requests to Dr G. A. Schultz. 
Post-ovulatory oocytes and embryos to be collected on Days 1-4 after onset of oestrus were recovered surgically at Alta Genetics Incorporated (AGI) of Calgary. The ovaries from each cow were removed, and each oviduct was flushed with $15 \mathrm{ml}$ PB-1 medium (Whittingham \& Wales, 1969) containing $4 \mathrm{mg}$ bovine serum albumin $/ \mathrm{ml}$ (BSA; Fraction V, Sigma Chemical Co., St Louis, MO 63178, USA) and 10\% heat-inactivated calf serum (Gibco, Grand Island, NY, USA). The adhering cumulus masses were removed by passing the oocytes up and down a fine-bore micropipette. Embryos to be recovered from cows on Day 5 after onset of oestrus or later were collected at AGI using a standard non-surgical procedure (Elsden et al., 1976). After collection, oocytes and embryos were washed by several transfers through M2 medium (Whittingham, 1971) before use in experiments.

Radiolabelling and electrophoresis of ${ }^{35}$ S-labelled material. Labelling of embryos and electrophoresis of ${ }^{35} \mathrm{~S}$-labelled proteins were carried out by the methods used by Gifford et al. (1987) with minor modifications. Embryos were transferred into $2-3 \mathrm{ml} \mathrm{M} 2$ medium and incubated at $37^{\circ} \mathrm{C}$ for $1 \mathrm{~h}$. The embryos were then cultured under oil in a prewarmed $50 \mu \mathrm{l}$ drop of M2 medium containing $0.83 \mu \mathrm{M}-\mathrm{L}-\left[{ }^{35} \mathrm{~S}\right]$ methionine (sp. act. $1253 \mathrm{Ci} / \mathrm{mmol}$; Amersham, Oakville, Ontario, Canada) or $0.75 \mu \mathrm{M} \mathrm{L}-\left[{ }^{35} \mathrm{~S}\right] \mathrm{methionine} \mathrm{(sp.} \mathrm{act.} 1330 \mathrm{Ci} / \mathrm{mmol}$ : Amersham) at $37^{\circ} \mathrm{C}$ in an humidified atmosphere of $5 \% \mathrm{CO}_{2}$ for $2 \mathrm{~h}$. Oocytes and embryos were then washed 3 times in $4 \mathrm{ml}$ volumes of fresh, ice-cold medium free of radioactivity, with a final wash in $4 \mathrm{ml}$ phosphate-buffered saline(PBS) pH 7.2(Dulbecco \& Vogt, 1954), to remove protein present in the medium. Washed individual oocytes or embryos were transferred along with a small amount of PBS into microfuge tubes and were disrupted by adding $25 \mu \mathrm{l} \mathrm{SDS}$ (sodium dodecyl sulphate)-dissociation buffer ( $62.5 \mathrm{~mm}$ Tris- $\mathrm{HCl}$, $\mathrm{pH} 6 \cdot 8$, containing $2 \%(\mathrm{w} / \mathrm{v}) \mathrm{SDS}, 10 \%(\mathrm{v} / \mathrm{v})$ glycerol and $5 \%(\mathrm{v} / \mathrm{v}) 2$-mercaptoethanol). The samples were stored at $-70^{\circ} \mathrm{C}$.

Measurement of trichloracetic acid (TCA)-precipitable radioactivity was conducted on $2 \mu l$ samples of the lysate, exactly as described by Gifford et al. (1987). The efficiency of counting of $\left[{ }^{35} S\right]$ methionine using 'Econofluor-2' or 'Aquasol-2' was calculated to be $77.6 \%$ and $75.3 \%$, respectively.

Samples $(12 \mu \mathrm{l})$ of dissociated extracts were resolved by sodium-dodecyl sulphate-polyacrylamide gel electrophoresis (SDS-PAGE) and fluorography as described previously (Gifford et al., 1987). The ${ }^{14} \mathrm{C}$-labelled molecular weight markers used were purchased from Amersham (myosin, 200000; phosphorylase b, 92 500; bovine serum albumin, 69000 ; ovalbumin, 46000 ; carbonic anhydrase, 30000; and lysozyme, 14300 ).

In-vitro labelling of embryos with $~_{3}^{3} \mathrm{H}$ Juridine. Embryos were transferred into a pre-warmed $50 \mu 1$ drop of M2 medium containing $5 \cdot 13 \mu \mathrm{M}-\left[5,6{ }^{3} \mathrm{H}\right]$ uridine (sp. act. $39 \mathrm{Ci} / \mathrm{mmol}$; Amersham) and incubated under oil at $37^{\circ} \mathrm{C}$ in an humidified atmosphere of $5 \% \mathrm{CO}_{2}$ air for $2 \mathrm{~h}$. Measurement of acid-precipitable radioactivity in washed embryos was conducted as for protein labelling studies. Tritium counting efficiency was $36 \%$.

\section{Results}

A steady decrease in the rate of incorporation of $\mathrm{L}-\left[{ }^{35} \mathrm{~S}\right]$ methionine into acid-precipitable material was observed between the post-ovulatory oocyte to the 8-cell stage (Table 1). In the 8-cell embryo, the relative rate of protein synthesis was, on average, $29 \%$ of that of the post-ovulatory oocyte. In stages from the 16-cell to the blastocyst there was a progressive increase in the rate of L- $\left[{ }^{35}\right.$ S]methionine incorporation (Table 1). The rate in the blastocyst was observed to be 20 -fold greater than at the 8 -cell stage.

Table 1. Incorporation of $\mathrm{L}-\left[{ }^{35} \mathrm{~S}\right]$ methionine into TCA-precipitable material by cow oocytes and embryos

\begin{tabular}{lll}
\hline \multicolumn{1}{c}{ Stage } & \multicolumn{2}{c}{$\begin{array}{c}\text { Incorporation } \\
\left.\text { (c.p.m./embryo/2 } \mathrm{h}^{*}\right)\end{array}$} \\
\hline Postovulatory oocyte & 9630 & $(4816-12418, n=6)$ \\
1-cell zygote & 8863 & $(4934-9514, n=9)$ \\
2-cell embryo & 5372 & $(4032-6638, n=4)$ \\
4-cell embryo & 4262 & $(4154-4372, n=2)$ \\
8-cell embryo & 2819 & $(2650-2988, n=2)$ \\
8-16-cell stage & 6520 & $(5122-8180, n=3)$ \\
16-32-cell stage & $7900 \quad(6256-9544, n=2)$ \\
32-48-cell stage & $29197(18976-39418, n=2)$ \\
Blastocyst & $56363(21660-91878, n=9)$ \\
\hline
\end{tabular}

*Values are the average of the number of individual oocytes or embryos $(n)$ assayed as shown in the parentheses. The numbers in parentheses give the range of values obtained. Counting efficiency was $76 \%$. 
The qualitative patterns of proteins synthesized at different stages of development are shown in Fig. 1. While minor differences in some radiolabelled polypeptides were detected between the oocyte and 4-cell stage (Lanes B-F, Fig. 1), the patterns were quite similar at one stage and the next. Marked changes in the pattern were, however, detected in radiolabelled polypeptides derived from 8- and 16-cell stage embryos (Lanes G and H, Fig. 1). The patterns in 16- to 32-cell embryos and blastocysts were similar to each other but distinct both from those produced by embryos before the 4-cell stage and by 8-cell and 16-cell stage embryos.

To measure rates of RNA synthesis, embryos at different stages of preimplantation development were incubated in vitro in the presence of $\left[{ }^{3} \mathrm{H}\right]$ uridine for $2 \mathrm{~h}$. We were unable to detect any

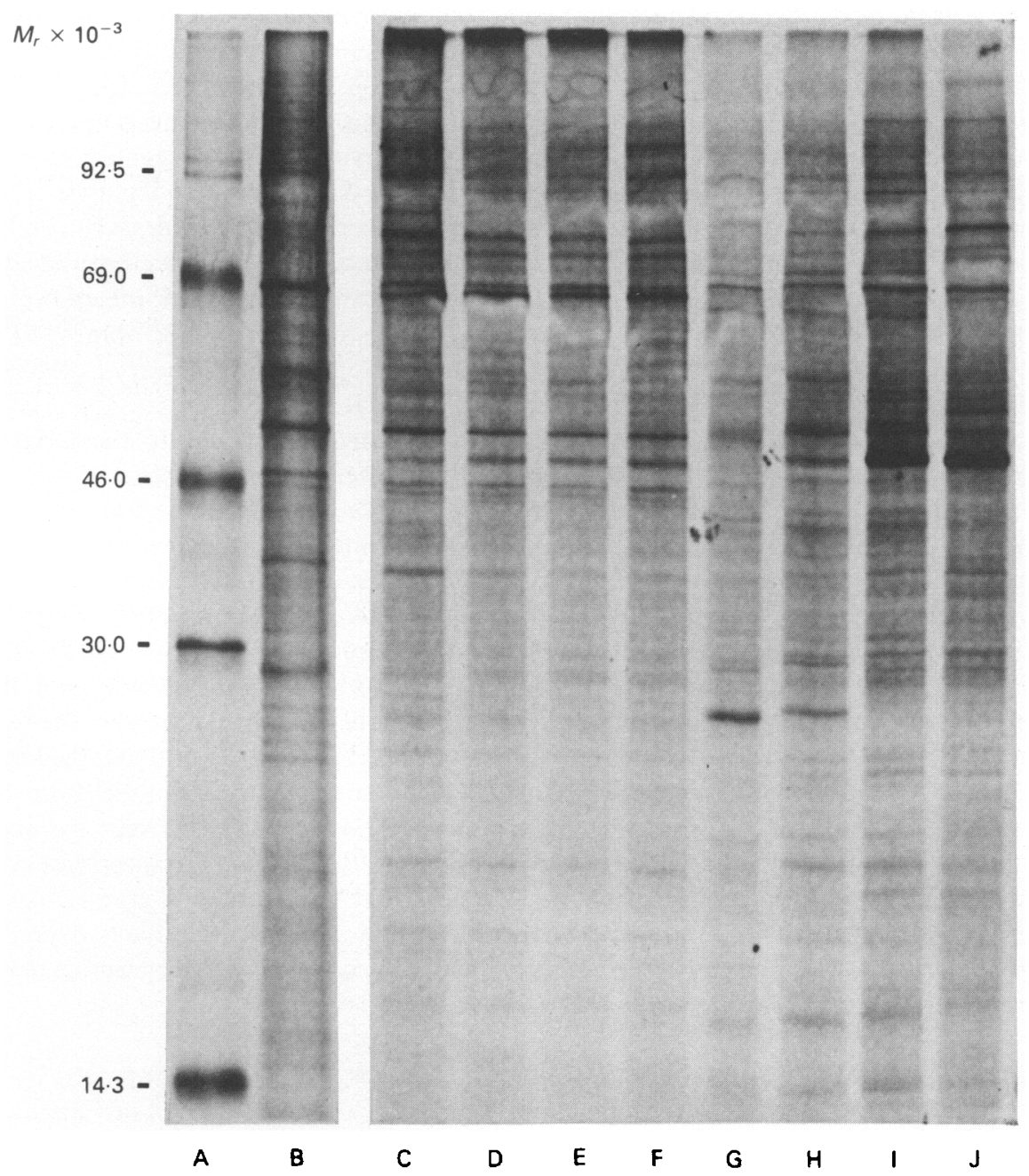

Fig. 1. Qualitative patterns of protein synthesis in cow oocytes and early embryos. Individual oocytes or embryos were incubated in medium containing $L-\left[{ }^{35} S\right]$ methionine for $2 \mathrm{~h}$. About 1800 c.p.m. of acid-insoluble radioactivity from each sample was analysed by one-dimensional electrophoresis and fluorography. The positions of ${ }^{14} \mathrm{C}$-methylated standards are identified in Lane A with numerical values $\left(\times 10^{-3}\right)$. Lane B, postovulatory oocyte; Lane C, 1-cell zygote; Lane D, 2-cell embryo; Lane E, 2-cell embryo; Lane F, 4-cell embryo; Lane G, 8-cell embryo; Lane H, 8-16-cell embryo; Lane I, 16-32-cell embryo; Lane J, blastocyst (Day 7). X-ray film exposure time was 22 days. 
incorporation of $\left[{ }^{3} \mathrm{H}\right]$ uridine into TCA-precipitable material before the 16-cell stage. The levels of radioactivity that were measured in a sample containing a pool of four 2-cell embryos and a sample containing a pool of four 8-cell embryos were indistinguishable from background. In three 16-cell embryos, an average incorporation rate of 42 c.p.m./embryo $/ 2 \mathrm{~h}$ was observed. For a series of morulae to early blastocysts ( $>32$-cells but $<48$ cells), the rate of $\left[{ }^{3} \mathrm{H}\right]$ uridine incorporation was $760 \pm 213$ (mean \pm s.d., $n=13$ ) c.p.m./embryo/ $2 \mathrm{~h}$.

\section{Discussion}

A major feature of the transition from maternal to zygote genome control in the mouse embryo is a marked change in the pattern of protein synthesis as the embryo proceeds through the first cleavage (Braude et al., 1979; Cullen et al., 1980). Some of these changes are due to differential mRNA activation, some are due to post-translational modification and some are due to differential polypeptide turnover (Howlett \& Bolton, 1985). During this period there is a loss of much of the maternal messenger RNA pool but transcriptional activity from the zygote genome is also activated (Piko \& Clegg, 1982; Giebelaus et al., 1983; Clegg \& Piko, 1983). The two-cell stage of mouse embryogenesis is, therefore, the point where developmental arrest occurs when embryos are treated with $\alpha$-amanitin (Golbus et al., 1973). Comparable sets of studies have been conducted to suggest that the switch from maternal to zygote genome control of early development occurs at the 8-cell stage in the rabbit (Manes, 1973; Schultz et al., 1973; Van Blerkom \& Manes, 1974). This transition period occurs at the 4-8-cell stage of human development (Braude et al., 1988) and the 8-16-cell stage of development of the sheep embryo (Crosby et al., 1988).

The experiments presented in this paper indicate that, from the 1-cell to the 8-cell stage of development of the bovine zygote, there is a decrease in the level of protein synthesis, with no major changes in the qualitative patterns of protein synthesis taking place during this period. At the 8-16-cell stage, several changes in the qualitative pattern of protein synthesis are evident. A new qualitative pattern of protein synthesis is established after the 16-cell stage, with this pattern persisting up to the blastocyst stage. The rates of protein and RNA synthesis also increase dramatically between the 16-cell and the blastocyst stages of development. The biochemical data on RNA synthesis in this report are consistent with previous studies in which, through use of autoradiographic techniques, $\left[{ }^{3} \mathrm{H}\right]$ uridine was incorporated into the nucleoplasm and nucleoli of cow embryos only at the end of the 8-cell stage (Camous et al., 1986). All of these findings are consistent with the interpretation that the maternal to zygote genome transition in the cow embryo occurs at the same time as that in the sheep.

The rate of radiolabelled methionine incorporation declines gradually between the oocyte and 8-cell stage in the cow embryo. The rate of protein synthesis also drops in the sheep embryo but, in this case, the fall is a sharp decline after the third cleavage rather than a gradual decrease in synthetic rate (Crosby et al., 1988). If this decrease in translational activity is due to degradation of maternal mRNA, then the cow and sheep embryo differ in the way that the programme of maternal control of development is regulated.

We thank Dr Steen Willadsen for supplying cow embryos. R.E.F. was supported by studentships from the Natural Sciences and Engineering Research Council (NSERC) of Canada and the Alberta Heritage Foundation for Medical Research. This project was funded by an NSERC operating grant to R.B.C. and a grant from the Medical Research Council of Canada to G.A.S.

\section{References}

Braude, P.R., Pelham, H.R.B., Flach, G. \& Labotto, R. (1979) Post-transcriptional control in the early mouse embryo. Nature, Lond. 282, 102-105.

Braude, P., Bolton, V. \& Moore, S. (1988) Human gene expression first occurs between the four- and eightcell stages of preimplantation development. Nature, Lond. 332, 459-461.

Camous, S., Kopecny, V. \& Flechon, J.E. (1986) Auto- 
radiographic detection of the earliest stage of ${ }^{3}[\mathrm{H}]$ uridine incorporation into the cow embryo. Biol. Cell 58, 195-200.

Clegg, K.B. \& Piko, L. (1983) Quantitative aspects of RNA synthesis and polyadenylation in 1-cell and 2-cell mouse embryos. J. Embryol. exp. Morph. 74, 169-182.

Crosby, I.M., Gandolfi, F. \& Moor, R.M. (1988) Control of protein synthesis during early cleavage of sheep embryos. J. Reprod. Fert. 82, 769-775.

Cullen, B., Emigholz, K. \& Monahan, J. (1980) The transient appearance of specific proteins in one-cell mouse embryo. Devl Biol. 76, 215-221.

Dulbecco, R. \& Vogt, M. (1954) Plaque formation and isolation of pure lines with poliomyelitis viruses. $J$. exp. Med. 99, 167-182.

Elsden, R.P., Hasler, J.R. \& Seidel, G.E. (1976) Nonsurgical recovery of bovine eggs. Theriogenology 6 , 523-532.

Flach, G., Johnson, M.H., Braude, P.R., Taylor, R.A.S. \& Bolton, V.N. (1982) The transition from maternal to embryonic control in the 2-cell mouse embryo. EMBO J. 1, 681-686.

Giebelhaus, D.H., Heikkila, J.J. \& Schultz, G.A. (1983) Changes in the quantity of histone and actin messenger RNA during the development of preimplantation mouse embryos. Devl Biol. 98, 148-154.

Gifford, D.J., Fleetham, J.A., Mahadevan, M.M., Taylor, P.J. \& Schultz, G.A. (1987) Protein synthesis in mature human oocytes. Gamete Res. 18, 97-107.

Golbus, M.S., Calarco, P.G. \& Epstein, C.J. (1973) The effects of inhibitors of RNA synthesis ( $\alpha$-amanitin and actinomycin D) on preimplantation mouse embryogenesis. J. exp. Zool. 186, 207-216.

Howlett, S.K. \& Bolton, V.N. (1985) Sequence and regulation of morphological and molecular events during the first cell cycle of mouse embryogenesis. $J$. Embryol. exp. Morphol. 87, 175-206.

Manes, C. (1973) The participation of the embryonic genome during early cleavage in the rabbit. Devl Biol. 32, 453-459.

Norris, M.L., Barton, S.C. \& Surani, M.A.H. (1985) A qualitative comparison of protein synthesis in the preimplantation embryos of four rodent species (mouse, rat, hamster, gerbil). Gamete Res. 12, 313-316.

Piko, L. \& Clegg, K.B. (1982) Quantitative changes in total RNA, total poly (A), and ribosomes in early mouse embryos. Devl Biol. 89, 362-376.

Schultz, G.A., Manes, C. \& Hahn, W.E. (1973) Synthesis of RNA containing polyadenylic acid sequences in preimplantation rabbit embryo. Devl Biol. 30, 418-426.

Van Blerkom, J. \& Manes, C. (1974) Development of preimplantation rabbit embryos in vivo and in vitro II. A comparison of qualitative aspects of protein synthesis. Devl Biol. 40, 40-51.

Whittingham, D.G. (1971) Culture of mouse ova. $J$. Reprod. Fert., Suppl. 14, 7-21.

Whittingham, D.G. \& Wales, R.G. (1969) Storage of twocell mouse embryos in vitro. Aust. J. biol. Sci. 22, 1065-1068.

Received 14 November 1988 